\title{
Toward a Trade War between China and the United State? Section 301 Investigation against China
}

Jie Liu*

Xiamen University School of Law

The United States Trade Representative ("USTR") has recently declared to initiate an investigation toward China under the Section 301 of the Trade Act of 1974. It seeks to determine whether measures China takes in regard to technology transfer, intellectual property ("IP"), and innovation are unreasonable or discriminatory so that those constitute burden or restriction on the US commerce. ${ }^{1}$ The legal action adds new evidence on the trade policy of 'America First' pursued by the Trump Administration. The investigation under Section 301, which includes 'Section 301, '2 'Super 301'3 and 'Special 301., Such legal process does not rely upon international law, but American domestic law to initiate trade investigation against American trade partners. By launching or threating to launch the Section 301 investigation, the US often succeeded in forcing its trade partners to make compromise, for instance, open their market to American goods and revive their domestic laws. Thus, it has long been complained as a unilateral means based on American hegemony.

As a matter of fact, the Section 301 investigation is not new for China. For instance, in 1992, a Section 301 investigation forced China to sign with the US a Memorandum of Understanding on IP. ${ }^{5}$ Furthermore, the US imposed a 100 percent punitive tariff on Chinese textiles, clothing and electronics in 1994 and 1995, respectively. ${ }^{6}$ Moreover, the USTR, at the request from the United Steelworkers Union, launched a Section 301 investigation toward China's cleanenergy policies and measures in 2010.

Why is then China targeted again in 2018? There are several reasons. First,

* Ph.D. candidate of International Law at Xiamen University. The author may be contacted at: liujieoo86@foxmail.com 
the US seriously suffered from the financial crisis happening in 2008 and has not recovered its economy yet. As the result, Donald Trump, during the president campaign in 2016, pledged that he would transfer to the 'America First' policy, which means a more aggressive trade policy. After taking the presidency, Trump should keep his promise. ${ }^{7}$ Second, since the accession to the World Trade Organization ("WTO"), China has remarkably expanded its trade volume and increased its trade competitiveness. In particular, the global economic crisis which hit nearly all developed countries fueled China's economy. The trade deficit between China and the US has not been effectively remedied. ${ }^{8}$ Third, the US argued that China failed to full comply with its obligations under the WTO agreements and the WTO mechanism does not live up to American expectation to make China a good complier. ${ }^{9}$ As a result, the US resorts to the Section 301 again.

How does China perceive and engage American trade investigation? First, China considers that any trade war would hinder the revival of global economy and damage the interests of many stakeholders in the US. Accordingly, the US should handle trade disputes in a responsible manner. In addition to China, another 10 "priority watch states" and 23 'watch states' are actually potential targets of the Section 301 investigation. Therefore, China perceives the Section 301 not only a mutual trade dispute between China and the US, but also American abandon of liberal multilateral trade system which it has advocate and defended for decades. Instead, China proclaims itself as a defender of liberal multilateral trade regime. ${ }^{10}$

Second, China is willing to negotiate with the US with the aim to resolve mutual trade disputes. China's Ministry of Commerce spokesman stressed that in either importation or exportation and either trade in goods or services, the Sino-US trade is fundamentally determined by the market and the choices of businesses and consumers in two countries. ${ }^{11}$ He also argued that there should be multiple factors which would contribute to the imbalance of the Sino-US trades. ${ }^{12}$ In particular, the restraint on the exports of high technology to China, which the US has huge comparative advantage, is a point of contention. What the US should do is not to launch the Section 301 investigation, but open its own trade market more widely.

Third, China will argue and defend its trade right under the WTO regimes. 
China is no longer a timid 'student' in the WTO as over a decade has passed since its accession to this global trading system. Rather, China has become an influential player in the WTO. China's trade officials are skilled to handle cases brought by other WTO members, while they are professional to file claims against other WTO members including the US. The US can launch the Section 301 investigation on its own, but the final judge of the WTO Dispute Settlement Body ("DSB") is not American. It is expected that the DSB at the request of China, will review whether the Section 301 investigation is in breach of American obligations to the WTO. ${ }^{13}$

Last, China should recognize that there is still room to enhance the legislation and enforcement in China. Good laws and effective enforcement can reduce the unfair trade practice and place different traders on an equal footing, making China-US mutual trade more sustainable.

\section{REFERENCES}

1. See USTR Announces Initiation of Section 301 Investigation of China, available at https:// ustr.gov/about-us/policy-offices/press-office/press-releases/2017/august/ustr-announcesinitiation-section (last visited on Feb. 6, 2018).

2. Section 301, No. 301 of the 1974 Trade Act. It contains substantive contents.

3. Super 301, No. 310 of the 1974 Trade Act. It aims to solve the problems of trade liberalization.

4. Special 301, No.182 of the 1974 Trade Act. It aims to solve the IP problems.

5. State Intellectual Property Office of PRC, China-U.S. Intellectual Property Negotiations Review, available at http://www.sipo.gov.cn/ztzl/zxhd/hh60/iphm/200909/ t20090921_476029.html (last visited on Feb. 6, 2018).

6. Id.

7. See President Donald J. Trump's Six Months of America First, The White House, July 20, 2017, available at https://www.whitehouse.gov/briefings-statements/president-donald-jtrumps-six-months-america-first (last visited on Feb. 6, 2018).

8. K. Loridas, United States-China Trade War: Signs of Protectionism in a Globalized Economy?, 34 Suffolk Transnat'L L. Rev. 405-27 (2011).

9. Supra note 1.

10. See MOFCOM Spokesperson: Response to the United States 301 survey of China [商务 部: 对美对华启动301调查强烈不满], available at http://www.xinhuanet.com/2017-08/21/ c_1121518510.htm; http://www.mofcom.gov.cn/article/ae/ag/201708/20170802630129. 
shtml (all last visited on Feb. 6, 2018).

11. A spokesman of China's Ministry of Commerce (MOC) responded to investigation of U.S. Section 301 on January 11, 2018 [商务部谈2018年中美贸易摩擦形势: 存在不确定因素], available at http://www.chinanews.com/cj/2018/01-11/8421545.shtml (last visited on Feb. 6, 2018).

12. Id.

13. He Li, Resurrection of “Section 301” in U.S. and WTO [美国“301条款”的复活与WTO], 12 J. Political SCI. \& L. [政法论从] 10 (2017). 